\title{
Geographic, Ethnic and Linguistic Composition of Afghanistan: Methodological rich points of Language Policy and Planning
}

Dr. Ayaz Ahmad ${ }^{*}$ Ms. Sana Hussan ${ }^{\dagger}$ Mr. Muhammad Safiullah ${ }^{\ddagger}$

\begin{abstract}
This paper evaluates the Language Policy and Planning's (LPP) Methodological Rich Points (MRP) in the geographic, ethnic and linguistic composition of Afghanistan. The theoretical construct is taken from the work of Nancy H. Hornberger on MRP in LPP. The paper explores a range of primary and secondary sources, and finds that the presence of inequality, marginalization and oppression in intra-ethnic and intralanguage group relations, sharing of resources and power account for neglect of the MRP in Afghan LPP. The geographic details in conjunction with explanation of historical process of migrations and conquests explains that most of the minority language speakers are concentrated in the difficult to reach areas of Afghanistan for their safety. Further, the limiting factors of Afghan geography explains the preservation of minority languages from the effects of majority languages. The study concludes with the proposal that it would be helpful to avoid the pitfalls of the current LPP in future by giving due attention to MRP.
\end{abstract}

Key Words: Afghanistan, Methodological Rich Points, Language Policy and Planning, Afghan Ethnic Composition, Afghan Linguistic Composition, Afghan Geography, LPP

\section{Introduction}

As the recent conflicts in Afghanistan has a significant linguistic aspect (Simonsen, 2004, p. 708), therefore, this paper explores the role of her geographic, ethnic and linguistic composition as deterministic forces in sculpting her Language Policy and Planning (LPP).

\section{Theoretical Framework and Research Methodology}

The study of language is normally covered by different branches of linguistics. However, the ubiquity of language in almost all spheres of human existence makes it necessary for many branches to become inter-disciplinary or multidisciplinary. During 1950s, in the emergent new world order (post World War

\footnotetext{
*Lecturer, Department of English, Abdul Wali Khan University Mardan, Mardan, KP, Pakistan. Email: ayazmardan@gmai.com

${ }^{\dagger}$ MPhil Scholar, Department of English, Abdul Wali Khan University Mardan, Mardan, KP,

Pakistan.

${ }^{*}$ Research Assistant, Humanity Research Council, Islamabad, Pakistan.
} 
II), language policy and planning started to form as an autonomous branch of linguistics, mainly for the better understanding of causes and effects of the instrumentalisation of language for economic, political, social, cultural and communicative ends. With the passage of time enrichment of the field has yielded rich dividend in the form of depth of scholarship and diversity of methodological and theoretical perspectives. Still one of the fundamental question remains, "Why do individuals opt to use (or cease to use) particular languages and varieties for specified functions in different domains, and how do those choices influences and are influenced by ......decision-making?" (Ricento, 2000), p.208. Hornberger (2015) has proposed an innovative approach for finding answer to this question. She propose that a diverse range of methods in the "toolkit" of LPP researchers may be used depending on the problem we address, i.e. "survey questionnaire, census and demographic data, linguistic corpora, interviews, policy documents, participant observation and participatory action; and an analytical toolkit embracing statistical, experimental, ethnographic, linguistic and discourse-analytic approaches." (Hornberger, 2015, p. 10). She considers Methodological Rich Points (MRP) as the realization of the "pressures and tensions" (Hornberger, 2013, p. 101)between practice and theory. Such pressures become greater where the nature and size of data is very diverse and complex. She offers the heuristics of Fishman (1971) as the starting point to find: who researches whom and what in LPP, where, how, and why? She identifies MRP in "Who researches whom?" by pointing out the relation and positionality of the researcher and object/subject of the research. Here maximizing "collaboration" with and "representation of" the research subject/participants as important for retaining relevance and utility of the research as emancipatory force especially for the marginalized. The MRP in second question, "What do the researchers study?" are elaborated as to cover the implicit and covert aspects of policy along the explicit and overt. "Contextualization" lead to the hidden aspects and offer more valuable understanding that can be used to pinpoint gaps in language policies from the perspective of rights of the marginalized language groups.

The next question, "Where do LPP researchers carry out their research?" is related to looking and caring for "heterogeneity" and "mobility" (as dynamic change) as MRP because researchers in attempt to generalize often favor typicality and ignore this aspect. The question, "Why do LPP research?" offers MRP in the form of transferability and particularity. Transferability is offered as the assessment of generalization to other cases from the study of the given. Particularity is the assessment which prohibit transferability. So, some of the findings would be particular and others would be transferable. The question, "How do LPP researchers collect, analyze and interpret data?" also offer MRP in the form "sufficiency" and "inferential relation between theory and data" (Hornberger, 2015). The presentation of MRP serves the critical function of 
using LPP research as an emancipatory tool to resist repressive and marginalizing practices.

Based on the construct of MRP in the above discussion, this paper offers rationalization of the geographic, ethnic and linguistic composition to point out how geography and ethnolinguistic composition point to the presence of LPP that is marginalizing and repressive, especially for the minority language speakers.

The paper is essentially exploratory and qualitative in approach. It selects and interprets such details that help in pointing out LPP related MRP in the geographic, ethnic and linguistic composition of Afghanistan.

The following questions are answered in this paper.

1. What geographic, ethnic and linguistic aspects of Afghanistan offer MRP in Afghan LPP?

2. How MRP in Afghan LPP can be used as remedial factors in ensuring rights of minorities?

Most of the data is secondary. Therefore, further studies that use primary data are required to verify the findings of this paper.

\section{Geographic Composition of Afghanistan}

This section describes geography of Afghanistan. Afghan geography is presented here as one of the causal elements in current ethnographic and linguistic making of Afghanistan. The geography of Afghanistan itself caused historical processes of forcing or limiting movements and settlement of people. The presence of an ethnic group in a region rich in natural resources provide opportunity of prosperity of the group and helps in the domination of the ethnic group's language over the language of other groups. Presence of natural resources acts as a determining force in the linguistic domination of certain groups over other groups.

Afghanistan occupies $650,000 \mathrm{~km}^{2}$. It is located at the south-western part of Central Asia. It lies in a subtropical zone and covers from $29^{\circ} 21^{\prime} \mathrm{N}$ to $38^{\circ} 30^{\prime} \mathrm{N}$ latitude and extends from $60^{\circ} 31^{\prime} \mathrm{N}$ to $75^{\circ}$ East longitude. It is surrounded in North by Central Asian Republics of former USSR, in west by Iran, on the south and east by Pakistan and the Wakhan region touches China in the northeast (Gopalakrishnan, 1982, p. 2).

Afghan topography presents a desolation and sparse population with mountainous spine and its branches that separate South Asia from Central Asia and forms the zone of separation between the eastern most bounds of Middle East and South Asia (Ramazani, 1966, pp. 9-11).

The climate of Afghanistan is continental with hot summer less precipitation and dry air as opposed to cold winter and some rainfall in most of the desert places, whereas in the northeast alpine conditions prevail with intense cold and short summers (Gopalakrishnan, 1982, p. 20). 
Geography and historical process reciprocally influenced each other in case of Afghanistan. Formation of Afghanistan in 1747 was based on the ruins of Moghul, Persian and Uzbek empires. Later in $19^{\text {th }}$ century its territory was the result of geopolitics of Russian and British expansion in the region (Gopalakrishnan, 1982, p. 2). Historically, Afghan boundary was imposed on the population to settle strategic interest of Russia and Great Britain. Afghanistan as a result of this process became land-locked buffer state. Therefore, there is lack of congruence between the ethnic and geographical boundaries of Afghanistan due to the process of "border engineering" (Hyman, 2002: 302). Afghan rulers were awarded with economic and military aid for their cooperation in boundary settlement (Gopalakrishnan, 1982, p. 3). Hindukush and its western extension is responsible for limiting historical migration to and from India and Central Asia/Middle East. The geography is also responsible for the preservation and lack of absorption of the emigrant people into Afghanistan as different regions remained isolated and provided isolation (Gopalakrishnan, 1982, pp. 23-24; Schurman, 1962). Therefore we find the eastern and southern parts as more homogenous from ethnolinguistic perspective, while in other areas where terrain is difficult we find heterogeneity (Orywal, 1983, pp. 3-17; Pstrusinska, 1990). Historically Khorasan - the current area of Afghanistan - was called the granary of Asia due to the abundance of fertile lands and valleys (Bellew, 1879, pp. 189224) and the lands commanded key position on silk route in the north-south and east-west commerce and communication helping in diffusion of social and cultural influences across Afghanistan (Gopalakrishnan, 1982, pp. 30-31).

Abundance of mineral resources in northern and eastern parts of Afghanistan was a cause of development plans related to exploration and exploitation of mineral resources in these areas and absence of such plans elsewhere. The mountain system in central and northern Afghanistan has mad connection between the north and rest of Afghanistan difficult. Geographical barriers results therefore in political and economic isolation of various regions of Afghanistan from each other. The geographical regions (based on physiography) have continuity with adjacent areas in neighboring states, and there is inclination of the population to each other in such contiguous region (Gopalakrishnan, 1982, p. 9).

The Afghan geographical restraints play important role in her politics and policies. As geographers find a causal relation between the policies and geographical features of a polity (Fawcett, 1919(1961); Freeman, 1958, 1968), the same stands true for Afghanistan (Gopalakrishnan, 1982, pp. 11-14). Harsh terrain responsible for independent nature of the Afghan population (Holdich, 1987, p. 386) and failure to develop a sustainable political and economic system (Gopalakrishnan, 1982, p. 11). Habitable tracts of lands and valleys with thriving population are cut off from one another by difficult to pass mountainous and desert terrain (Gopalakrishnan, 1982, p. 14). Impassable terrain made the 
development of rails and roads difficult that resulted in weak central control on the outlying regions (Gopalakrishnan, 1982, p. 5; Holdich, 1987, p. 386). River beds that support population become the center of political activity (Gopalakrishnan, 1982, p. 15). Geographical restraints are responsible for her division in four regions i.e. northern, southern, eastern and western. This distribution corresponds to the existence four river basins i.e. Kabul river basin, Oxus river basin, Siestan basin and Hari Rud Basin. This division of Afghan topography is responsible for the emergence of southern, eastern, northern and western administrative regions (Fraser-Tytler, 1967, pp. 6-7; Gopalakrishnan, 1982, pp. 7-8; Stamp, 1967, pp. 178-181). Despite current division of Afghanistan into administrative units, geography facilitates division in fewer regions. In the start of twentieth century we find her divided into five provinces (regions) i.e. Herat, Kabul, Kandahar, Afghan Turkestan and Badakhshan each under the rule of a governor (Hamilton, 1910, p. 198; Holdich, 1904, p. 56). Bellew divided Afghanistan into four regions on the basis geographically imposed similarities on population. His division include Roh and Kabul, Zabul and Siestan, Hari and Ghor, and Balkh and Badakhshan (Bellew, 1879, pp. 194195). Oxus and Kabul river basins hosts cities having military and economic strategic importance (Ginsburg, 1958, pp. 683-688; Gopalakrishnan, 1982, pp. 2, 24). Shifting of capital from Kandahar to Kabul in 1772 by Timur Shah shows an effort occupy a strategic place that is free from regional influence (Holdich, 1904, pp. 80-100).

We find the current geography of Afghanistan a product of historical process wherein the contributing factors being strategic situation on the economic corridor of silk route and becoming a military buffer zone between the northward expanding of British rule in India and southern expansion of Russian empire in Central Asia (Gopalakrishnan, 1982, p.1). This land-locked, remoteness and buffer status for Afghanistan resulted in extreme poverty (Prescot, 1968, pp. 140; 1972, pp. pp.i-xiii). The restricting pressure on economy and politics due to geography made Afghanistan dependent on transit states who provided partial access to their transport facilities and forced her to make transport arrangement to suit the offered transit corridors. These arrangements carried implications for internal politics of Afghanistan (Gopalakrishnan, 1982, p. xiv). Strategic position of Afghanistan made her a prize for external powers and drew economic assistance from the regional and international powers and sometimes necessitated political intervention (Gopalakrishnan, 1982, p. 1). In modern times the borders of Afghanistan were decided by the Russian and British empires. This is the reason behind the ethnolinguistic groups in Afghanistan have continuity across border in all neighboring states. For instance, Wakhan corridor has been given to Afghanistan by the past colonial powers (Russia and Britain) to keep their territories separated. Similarly, half of the Pashtun population was lost to British India in this settlement between Russian and Britain. In Afghanistan geography 
as a determinant of human relations become important in forming relation between linguistic groups. The plains where people live remain isolated "islands" with little communication with other regions (Hilali, 1990, p.57). Many valleys in Afghanistan remain isolated for the most part of year people there become localized in social, political and economic sense. Lack of communication in the form of roads makes most of the terrain inaccessible and disconnected from the center (Kangas, Winter 1994, p.107).

\section{Ethnic Composition of Afghanistan}

This section is continues exploration of MRP in the ethnic composition of Afghanistan. Due to importance of ethnic identity in the formation of national identity, this subsection explores those aspects of Afghan ethnicity that play an integrative or disintegrative role in the national unity. Lack of authentic census (as discussed in second chapter due to political maneuvering by ethnolinguistic groups) necessitates dependence on survey where bias cannot be ruled out. Such condition makes reliable judgment about actual political power of the ethnic groups difficult, and it potentially create hurdle in the way of quality research based on demographic composition of Afghanistan. Pashtun, Tajik, Hazara and Uzbek are discussed here as the major ethnic group and the rest are treated as minor groups.

Scholars theorize the outcome of melting pot in case of a land where continuous inflow of migrants with different ethnic identities take place. There such people lose their old identities and form a new identity (Sollors, 1986; Zangwill, 1909/1921). In Afghanistan, such fusion of ethnic group failed to take place (as explained in preceding section on geography). Being an amalgam of cultures and ethnicities, Afghanistan failed to organize this diversity into an effective unity. This unity was contested by the ethnic groups whenever the central authority weakened, but extended isolation provided opportunity for the emergence of political order eventually (Gopalakrishnan, 1982, p. 4).

Pashtuns comprise the most powerful political and the most numerous ethnic group in Afghanistan (N. H. Dupree \& Gouttierre, 2001) that ruled (without a brief Tajik rule of Habibullah earlier in 1929 and recently by Mujaddidi and Rabbani in 1992-96) throughout the history of Afghanistan. They populate south and eastern part of Afghanistan as majority, whereas they can be found as a major minority in all parts of Afghanistan due to the policies of Amir Abdur Rahman. Majority of Pashtuns follow Sunni sect. Pashtu is their language, though most are bilingual Dari speakers. After demarcation of Durand Line in 1893, a considerable number of Pashtun became part of, first of British India, and then of Pakistan. Genealogically, Western writers consider them descendants of Israelites, but more acceptable view based on scientific facts trace them to Aryan. Pashtun society is tribal, with a significant element of nomadism. Most Pashtuns 
in modern times have elected a settle life with a tendency to Urbanization, still Pastoral nomadism (as Kuchi life) and rural agriculture subsistence farming continues as a major force. Military has remained a favourite profession among Pashtuns (leaving commerce to Tajiks and other ethnicities). Ghilzai and Durrani are prominent Pashturn tribal lines in Afghan history (N. H. Dupree \& Gouttierre, 2001). The national adjective (Afghan) and the name of modern state (Afghanistan) are Pashtun contributions especially "Afghan" is begrudged by some scholars as an authentic representative of ethnic minorities (Mousavi, 1998). However, through constitutional guarantees and generalization Afghan now stands for all citizens of Afghanistan.

Most Pashtuns are related to farming though other professions such as merchandize and construction are also practiced by them, whereas some tribal lines such as Muhammadzai and Ghilzai specialize in administration remaining a dominant force therein (N. H. Dupree \& Gouttierre, 2001).

After Pashtun, Tajik remains the next most important ethnicity of Afghanistan. Common estimates set their share of population at $30 \%$, after Pashtun migration during Afghan civil war their percentage in Afghan population has expanded from $25 \%$ to one $33 \%$ of the total population (Jawad, 1992, p. 11). Tajiks like living in cities, so they remain a majority in Kabul and Herat, where they play key role in the economic, social and political activities (N. H. Dupree \& Gouttierre, 2001). Traditionally they are in majority in norther areas of Afghanistan, such as Panjshir, Samangan, Baghlan, Takhar, Parwan and Badakhshan provinces. They speak Dari which closely resemble in lexicon, phonology, morphology and syntax (Jawad, 1992, p. 11). They traditionally form the educated urban circles in the capital, Kabul and Herat (Jawad, 1992, p. 11).

In historical records the oldest people of Afghanistan were called Aryans (Qums, 1983, p. 16), with the passage of time and arrival of peoples increasingly made Afghanistan multi-ethnic (Sarabi, 2006, pp. 8-9). There lacks consensus on the origin of Afghan Hazara (Poladi, 1989, p. 15). One approach establish Hazara to be the indigenous people (Ferrier, 1857, p. 220; Habibi, 1962, p. 2; Sharistani, 1981, p. 30). Hazara in other approach are considered the descendants of Mongol army who chose to stay and repopulate the area after Genghis Khan conquests stopped (Habibi, 1962, p. 3; Mousavi, 1998, p. 1) the second assumption is based on Hazara resemble with Chinese people-having Mongoloid features (Bellew, 1880, p. 110; Mousavi, 1998, p. xiii). Hazara people speak Hazaragai, a dialect of Dari (Poladi, 1989, p. 14; Sarabi, 2006, p. 13). The region of their settlement is known as 'Hazarajat' including parts of central provinces of Oruzgan, Ghaur, Herat, Frah, Qandahar, Parwan, Baghlan, Balkh and Badghis (Mousavi, 1998, p. xii). Majority of Hazra follow Shia sect of Islam (Bacon, 1951, pp. 4-7; Mousavi, 1998 , p. xiii). During $17^{\text {th }}$ century they embraced Islam under the influence of Persian rulers who were professed the Shiite sect (Schurmann, 1962, pp. 1-104). In 2000, they were believed to be around 2.5 million (Johnson, 2000). However, 
this figure is disputed by Hazara scholars who claim that the count of Hazara is systematically misreported and minimized in order to marginalize them. They claim that this figure was more four million in 2000 (Mousavi, 1998, p. 40; Rashid, 2000, p. 117; Sarabi, 2006, p. 29). Hazara people face a wide range of discrimination that stem from faith, race and language they have (Mousavi, 1998, pp. 63-81; Orazgani, 1913, p. 6) especially at the hands of Pashtuns (Hussain, 2003, p. 53). Hazara nationalism was shaped by this discrimination and it emerged in establishment of Hizb-e-Wahdat (Hussain, 2003, p. 62; Maley, 1998, pp. 200-210; Mousavi, 1998, pp. 6-7), that unified the previously divided people of Hazrajat (Harpviken, 2009).

Uzbeks belong to the Turkic race and their facial features remain distinct from Tajiks and Pashtuns (Goodson, 2001, pp. 14-16). However, culturally they are closer to Tajiks than to Pashtuns. They also prefer Dari over Pashto as second language (Alsanov, Gafferberg, Kisliakov, Zadykhina, \& Vasilyeva, 1969; Magnus \& Naby, 1998, p. 17; Naby, 1984, p. 5). Ethnicity became important as access to and control of education, political power and other resources was determined by state on the bases of ethnicity (Shahrani, 2002). Despite belonging to the same sect inter-ethnic marriages are not common in Afghanistan (Goodson, 1998, p. 274). Uzbeks successfully mobilized during the Afghan Civil War of 1990s under Junbesh-i-Milli (Bleuer, 2007, p. 1).

In Afghanistan, Uzbeks as minority were oppressed by the Pashtun rulers (L. Dupree, 1973, p. 161; Rais, 1999, p. 5) especially Amir Abdur Rahman. In the north undue force was used by the Amir to subdue population (Shahrani, 2002, p. 718). The Afghan minorities traditionally resent the Pashtun oppressive domination (Goodson, 1998, p. 271; 2001, p. 16), though some Pashtun claim to be the original inhabitants of Afghanistan so they are justified in oppressing minorities (Grevemeyer, 1987, p. 144). Before internal colonization of norther areas by Pashtuns through Amir Abdur Rahman policies, these areas had negligible Pashtun presence (Shahrani, 1998, p. 221) at that time the area was dominated by Uzbeks from $16^{\text {th }}$ century AD onwards (R. Tapper, 1984, p. 244). When Amir Abdur Rahman settled Pashtuns in the Uzbke area and gave them authority over Uzbeks, the cumulative effect over the next century was of resentment and hatred. This animosity helped in uniting them and politically awakened them (Barfield, 1981, p. 30; N. Tapper, 1991, p. 29). In 1990s the Uzbek armed groups showed unity when they were alarmed by resurgence of Pashtun domination in the form of Taliban (Khashimbekov, 1994, p. 37).

The population of Nuristani people stands at 100,000 and they are concentrated in the area between Kalash (Paksitan), Tajiks of Badakhshan and Pashtuns of Kunar (Jawad, 1992, p. 12). Before 1880, their area of settlement was called Kafiristan, after their forced conversion to Islam this area was renamed as Nuristan (Jawad, 1992, p. 12). Nuristani live in four valleys (Kati, Waighali, Ashun and Pursun) in Hindu Kush ranges. Each valley houses a 
distinct linguistic group. Animal farming constitute important economic activity as the agricultural land is scarce (Jawad, 1992, p. 12). As educational facility is scarce, migration to urban centres is undertaken to pursue education (Jawad, 1992, p. 12).

Kirghiz and Wakhi inhabit Pamir and Wakhan, a marginalized and neglected area in Afghanistan (Shahrani, 2013, p. xxvii). In 1973 Kirghiz population was about 330 households with a total number of 2400 persons and their main profession continues to be animal husbandry. They inhabit the extreme north and south of Wakhan corridor. Krighiz are traced back to Uralic, Mongol or sometimes to independent lineage with a consensus that they are not original Turks. Their first mention is in first century AD in an Orkhon language script. Being at their height in $8^{\text {th }}$ century AD, their defeat at the Karakhanid state the dispersed pursuing agriculture or herding (Boutros-Ghali, 1992, p. 1025; Lewis, Simons, \& Fennig, 2015, p. 105). Kirghiz migrated to Afghan Wakhan in large number in 1916 (Shahrani, 2013, p. 49). Before fixing of border in the Great Game between Britain and Russia Kirghiz and Wakhi people freely moved across border for grazing pastures (Shahrani, 2013, p. xiii). Kirghiz society is hierarchical where intermarriage between elite and non-elite is not practiced (Shahrani, 2013, p. 59).

Wakhi people who are also known as Pamir Tajiks live at high altitude of Afghan Pamirs along the sides of upper parts of Oxus river and its key tributary the Sarhad river. The total number of being 6000 peasants as they are confined only to cultivation (Shahrani, 2013, p. xxxviii). In nineteenth century the area was sparsely populated and its inhabited were reported to be merely a few thousand at most (Ryan, 1995, p. 310). While Kirghiz are Sunni Muslims, Wakhi people profess Shia sect of Islam (Shahrani, 2013, p. xxxi). Uzbek and Kirghiz dialects belong to Turkic language dialects and are mutually intelligible (Shahrani, 2013, pp. xxxii-xxxvii). Wakhi are the ancient Iranian stalk of people originated in Turkistan and inhabiting the area as far back as the Zoroastrian period (Kimminich, 1993). They speak Wakhi language a branch of ancient IndoIranian language (Eide, 1993, p. 455; Lijphart, 1996, p. 1103). Being adherents of Shia sect, Wakhi people face discrimination at the hand of Sunni administration appointed by the centre.

Baluchis and Brahuis collective population stands at 300,000. They reside in pastoral lands of south-west and south and follow Sunni sect of Islam. Their population is dispersed between Iran, Afghanistan and Pakistan (Jawad, 1992, p. 12). Each group speak a distinct language i.e. Baluchi and Brahui (Jawad, 1992, p. 12). The Baluchis are divided and oppressed minority, who continue political and armed resistance against this oppression (Wirsing, 1987).

\section{Linguistic Composition of Afghanistan}

Afghanistan is a multilingual state. Total number of languages spoken in 
Afghanistan is 40 (excluding one extinct language). Out of these 10 are troubled or dying languages and the rest are safe with 4 languages having institutional protection (Lewis et al., 2015). Due to unequal control of power by the speakers, all languages do not enjoy equal domination across various resources. The following discussion highlights the features that are responsible for linguistic inequality. Among autochthonous languages, Pashto and Dari are treated here as major languages (due to domination across domains of power) due to potential of these two languages to effect linguistic imperialism in Afghanistan, whereas other languages are treated as minor languages (whether threatened or not) and effects of the major languages domination is explored in the sociolinguistic characteristics of the languages spoken there. Language history, relation among languages (as language family), linguistic geography, and social aspects are explored that affect the process of national integration.

In Afghanistan some languages have a significant number of first language speakers whereas other languages are spoken elsewhere as first language but is learnt and spoken in Afghanistan as second language. Languages that are spoken in Afghanistan by local population as their first language are "autochthonous' to Afghanistan and those languages that spoken and learnt as a second language can be termed as 'exochthonous' languages. Foreign language can be taken as a nonindigenous language, which is learnt and spoken by the indigenous population of an area (Pearsall \& Trumble, 1995). In autochthonous languages, we can include Pashto, Dari, Turkic languages, Dardic languages and other minor languages. Out of these languages Pashto and Dari belong to Indo-Iranian group. Most of the Afghans speak Iranian languages. In the Northern and north-western regions various Turkic, Dardic-Nuristani and Pamir languages are spoken.

In the absence of a valid census, total population of Afghanistan is estimated to be $32,738,376$ (CIA, 2009). The population size of the speakers of major languages is for Afghan Persian or Dari, 35\% for Pashto, $11 \%$ for Turkic languages (primarily Uzbek and Turkmen) and 4\% for other 30 minor languages (primarily Balochi and Pashai). Majority of Afghans are bilingual. In 1986 the estimate of Pashto speakers was 6.5 million and the Dari speakers were estimated to be around 4.1 million with one million speakers of Hazagai dialects, Turkic languages and Dardic languages (Majrooh \& Elmi, 1986). English, French, Russian and German are major exochthonous or foreign languages in Afghanistan (Irshad, 2003). According to Katzner, in 2002 the population estimate of Afghanistan was 25 million in 2002 and Pashtun amounting to 15 million speak Pashtu. Out of the remaining 10 million in the rest of the population 8 million speak Persian known as Dari and in the northern regions there are 2 million speakers of Uzbek and half million speakers of Turkmen and about 0.3 million Baluch speakers in the south (Katzner, 2002) p.339. In Afghanistan some ethnic minorities like Brahui, Kurdish and Moghol have largely lost their language and shifted to the majority languages in Afghanistan 
Geographic, Ethnic and Linguistic Composition of Afghanistan: Methodological rich points of Language Policy and Planning 
the known dialects in Afghanistan. All dialects are mutually intelligible with around $90 \%$ vocabulary being lexically identical. L1 literacy rate is around $28 \%$. Dari enjoys national status under 2004 constitution. It is used in all domains but is dominant in education (primary and secondary level), media and films. It enjoys a positive attitude of Afghans. It is placed on EGIDS level 1 meaning it is the national language well protected and growing (Lewis et al., 2015).

Sir William Jones the famous Orientalist linguist took interest in it and came up with a systematic description attempted to relate it to other languages (Brown \& Ogilvie, 2009) p.850. In ancient times the dialect that was spoken in Persian courts was called "Parsiay-e-Dari" meaning the Persian of the court. Dari spread from Persia to Afghanistan through the Persian court in Kabul and there it has still another name, Kabuli. In Afghanistan, Dari was initially affiliated with the Persian domination and its spread there was largely due to its use in the domains of power (Dalby, 2004) pp.493-95. Regional varieties evolved in Afghanistan such as Kaboli in Kabul, Herati near Iranian border region, Aymaqi in vicinity of Herat along Iranian border and some other regional borders, and Afghan Tajiki in the norther region near to the border of Tajikistan (Windfuhr, 2009) p.417.

Dari is written in Arabic script and has a large number of Arabic loan words. These effects passed from Persian to Urdu and Turkish. In Afghanistan till 1933 it was the only of official language. The minority ethnic groups in the process of assimilating chose Dari as the language of choice when they had to learn a second language of wider communication. Nomadic Hazara, Aimaq and a number of Pashtuns became bilingual learning Persian as their second language to be used for communication with other communities (Dalby, 2004) pp.493-95.

Map showing the regions where Dari and other Persian dialects are spoken

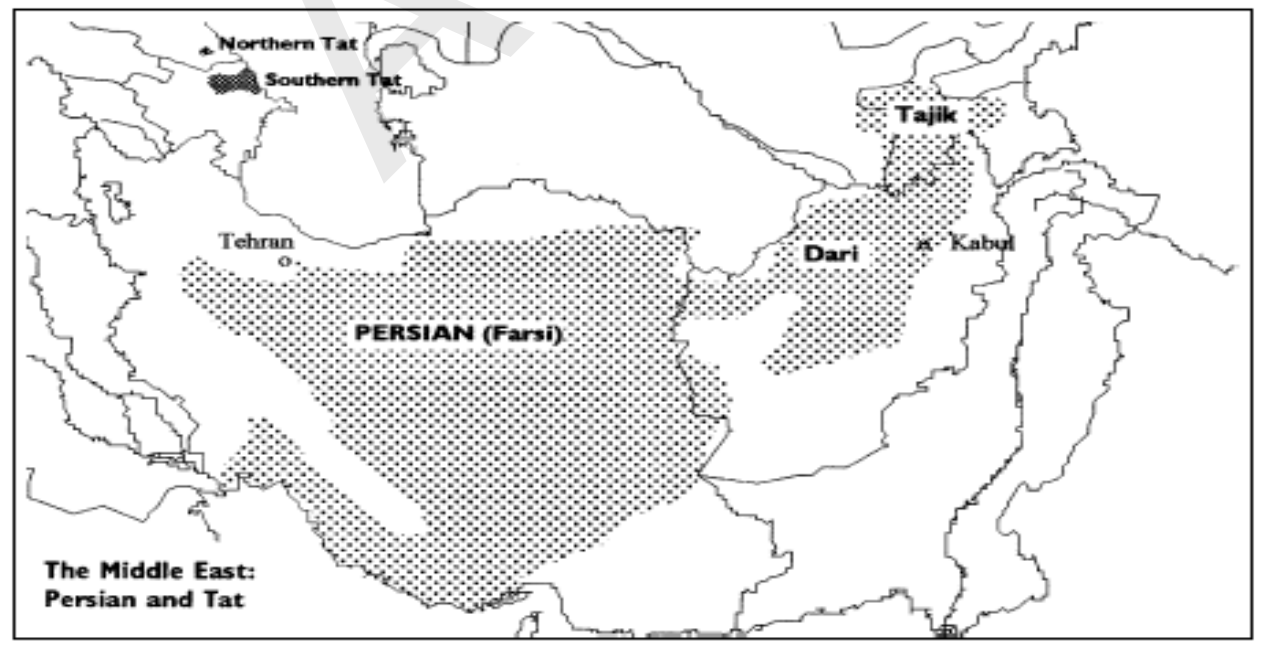

(Dalby, 2004: 493). 
Geographic, Ethnic and Linguistic Composition of Afghanistan: Methodological rich points of Language Policy and Planning

\section{Pashto}

Pashto is the major language of Afghanistan and Pakistan. The estimated population is 22 million and diaspora of 2.5 million in Karachi and Iran (Robson \& Tegey, 2009). In another estimate Pashto speaking population is placed at 40 million (Steptfonds, 2009) pp.845-6. Pashto is spoken in Kandahar, Zabul, Helmand, Uruzgan, Nimroz, Farah, Herat, Badghis, Nangrahar and adjoining area. It is L1 (First Language) of ethnic Pashtuns. It has two dialects, Southern and Northern. $80 \%$ lexicon is similar between northern and southern dialects. Alternative terms of Pakhto, Pashtu, Pushto and Yousafzai Pashto. It is used in education at primary level, along presence in media, film and TV. It enjoys national status with EGIDS level 1. Pashtun (educated or engaged in business) living in Dari speaking areas are bilingual in Dari. Literacy rate is low among Pashto speakers especially in rural areas (Lewis et al., 2015).

The oldest work in Pashto is a multilingual book of verses in Arabic and Pashto at the sixteenth century by Bayazid Ansari founder of Roshaniya movement. In another work of the earlier times by Khsushkhal Khan Khattak the Kandahari dialect was used. Till 20th century due lack of standardization agreement on the correct Pashto could not be achieved. Lack of standardization affected adopting Pashto in the domains such as administration, legislation, education and commerce (Robson \& Tegey, 2009).

Pashto has two dialects the soft dialect is spoken in southern Khyber Pakhtunkhwa, Baluchistan and regions of Afghanistan and the hard dialect is spoken in the areas of Peshawar and Northern Khyber Pakhtunkhwa province of Pakistan. In hard dialect Pashto is spoken as Pakhto and in soft it is Pashto (Katzner, 2002) p.164-5.

Pashto is the eastern Iranian branch of Indo-European language family. It gained official status in 1936 in Afghanistan along the erstwhile alone official language, Dari. The split between eastern or Peshawari dialect and western dialect that is known is Kandahari became marked when speakers of Peshawar dialect came under the British dominion and speakers of Kandahari dialect were integrated into the remaining state of Afghanistan. In seventeenth century we find a number of writing from poets, sufis and mystic writers. In twentieth century Pashto saw rapid growth due to application of this language in journalism, education and extensive literary genres (Campbell, 1995) p.379. Historically the domination of Pashtun in economy and politics of Afghanistan, provided their language a unique position among other languages (Dalby, 2004) p.492. Pashto also denotes the traditional code that Pashtun follow and Pashtun denotes the sense of nationhood in Pashtun (Comrie, 2009). 
Dr. Ayaz Ahmad, Ms. Sana Hussan and Mr. Muhammad Safiullah 
Geographic, Ethnic and Linguistic Composition of Afghanistan: Methodological rich points of Language Policy and Planning

\section{Balochi (Western)}

With a total regional population of four million this language has around 0.2 million speakers in Afghanistan. Still it is recognized as one of the national languages. It is a language belonging to Iranian family. Half a million speakers of this language work in Middle East (Dalby, 2004) p.65. Balochi is classified as Northwestern Iranian language. The area where it is mainly spoken happens to be Southeast of Afghanistan as they were forced to migrate from their original home through Arab and Mongol conquests. Balochi has contact with other languages of neighborhood. In Afghanistan it is in contact with Dari and Pashto and in Pakistan it is influenced by Urdu and Sindi and live in symbiosis with the Dravidian Brahvi speakers. Baluchi is neither official language nor the language of education in any of the countries where it is spoken. Due to low esteem, standardization of Baluchi did not take place. The efforts for the preservation and promotion of this language mostly originate from private supporter of this language. Baluchi has several regional dialects because the country where it is spoken has some other language used for education and other domains of power. In Afghanistan the southern dialect of Balochi is spoken (Windfuhr, 2009) p.6347. Six distinct dialects of Baluchi can be identified on the basis of lexicon and syntax (Brown \& Ogilvie, 2009) p.134. In Afghanistan, it is placed on level 5 of EGIDS that means it is developing there. Most Brahui speak it as their L2 (second language). In Afghanistan it is spoken in Helmand and Zarang areas (Lewis et al., 2015).

\section{Parachi}

Parachi is the language of population inhabiting north-east of Kabul in Nijrau and Tagu villages (Lewis et al., 2015). It has a collective population of 3500 speakers (Kieffer, 2009). Till 1924 its speakers were much more than they are now. However, the speakers have become bilingual or plurilingual. And it is only used by them in personal communication mostly in the extended families. It is placed on EGIDS level 7 meaning it is shifting to become extinct. With L1 literacy at zero and L2 literacy at $15 \%$, research on this language has produced dictionary of this language. Its dialects include Ghujulan, Pachanghan and Shtul (Lewis et al., 2015).

\section{Wakhi}

Wakhi is an East-Iranain language belonging to Pamir languages. Tajikistan and Afghanistan are its home in the upper Amu Darya. It is also known as Khwar and Shina. Total population of this languae is less than 0.1 million dispersed in Afghanistan, Pakistan, China and Tajikistan. Spread in to Pakistan has taken 
place in the twentieth century. Alternate names or spelling for this language include Khik, Khiwar, Vakhan, Wakhani and Wakhigi. Its total population is 17,000 in Afghanistan with total speaker standing at 58,000. In Afghanistan its speaker live in Badakhshan province and Wakhan. It is an Indo-Iranian and Pamir language. It has Gojal, Ishkoman and Yasin dialects with greater than $80 \%$ lexical similarities. Its speakers are predominantly Shi'a Muslim (Lewis et al., 2015).

\section{Major Turkic languages}

\section{Uzbek}

It is one of the Afghan languages which has been given national status. In Central Asian states it is spoken by twenty five million while two millions of these are in Afghanistan (Katzner, 2002) p.140. Uzbek is part of Turkic language family. Its speakers are concentrated in lower Zerafshan area and upper Syr Darya valleys (Brown \& Ogilvie, 2009) p.1145. Majority of Uzbeks can speak Dari as second language, especially in cities. On EGIDS language vitality, it has level 2 that translates it being a vigorous language. It enjoys constitutional recognition in Jawzjan, Saripu, Faryab and northern areas. It is similar to northern Uzbek spoken in Central Asia. L1 literacy stands at $1 \%$ and L2 at 2\%, with L1 literacy being increasing. It is branch of East Turkic family in Altaic line. It enjoys positive Afghan attitude. It has been introduced in education at primary level in northern areas, also present in media (print and electronic). It is the L1 of ethnic Uzbeks (Lewis et al., 2015).

Uzbek is the second largest language of Turkic family of languages after Turkish. It is named after Uzbek Khan who converted to Islam in the $12^{\text {th }}$ century. Uzbeki is the Karlu-Khorasanian sub-group of western Turkic or Hunnic language. Once it enjoyed prestige and power when it was the language of the Turkic khans and kings such Timur (Campbell, 1995) p.563. Uighurs and Uzbek have similarities with each other and exchange of lexicon and structure is abundant in the two languages. The regions where Uzbek language dominated is nowadays divided between Uzbekistan, Afghanistan and Kazakhstan (Dalby, 2004) p.665. However, in Afghanistan, Arabic script continues to be used for the Uzbek language (Brown \& Ogilvie, 2009) 1145-6.

\section{Turkmen}

Turkmen is spoken in Jawsjan, Faryab, Herat, Samangan, Baghalan, Badghis, Kunduz, Helmand and Kabul spoken by ethnic Turkmen. Its L1 population in Afghanistan is 1.5 million, however, majority Turkmen language speakers live outside of Afghanistan. On EGIDS language vitality scale it has level 5 (meaning 
dispersed). It is the statutory provincial language in Turkmen border areas. Turkmen is mostly used in rural areas (Lewis et al., 2015).

It is the national language of Turkmenistan. It is a branch of Altaic family of languages in Afghanistan. At one time Arabic script was used in all places for writing it. The introduction of Roman and Cyrillic script after the integration of Central Asia in USSR helped the Turkic language speakers integrate into Soviet system. In Afghanistan still the Arabic script is used by the speakers of this language (Katzner, 2002) p.139. Writing started in Turkmen language in $20^{\text {th }}$ century (Dalby, 2004) p.655.

\section{Yughur}

Uyghur belongs to the southeastern group of Turkic languages. At least 10 million people who live in the Chinese xinjiang province speak Uyghur. Because of the proximity to Kirghistan, Tajkistan, Kashmir and Afghanistan speakers of this language spill over to these neighborhoods. This combined Diaspora is estimated to be half million. They were initially vassals of Turks in Mongolia but in $8^{\text {th }}$ century Uyghurs defeated them and establish their own empire which extended from Baikal to the Mount Altay. In earlier time Sogdian influenced the Uyghur development and later, contact with Persian and then with Russian influence the Uyghur language. In recent past the rise in number of Chinese speaker is producing permanent imprint on Uyghur language (Brown \& Ogilvie, 2009) pp. 11142-3. In Afghanistan it is recently imported language with a population of 3,000 (Lewis et al., 2015).

\section{Semitic Language}

\section{Arabic}

Arabic in Afghanistan is spoken in Dawlatabad, Yakhdan, Jawzjan and Sheberghan areas. Its alternate names include Bukhara Arabi, Jugari and Tajiji Arabic. Its population is 5,000 and is decreasing being placed on $6 \mathrm{~b}$ of EGIDS language scale that means it is a threatened language. It belongs to Afro-Asiatic and Semitic branch of languages. As other people do not use this dialect it is borrowing heavily from Dari language, therefore a shift to Tajiki is taking place. Its speakers Sunni Muslims. This ethnic group is endogamous and do not marry into other ethnic groups (Lewis et al., 2015).

\section{Dravidian Language}

\section{Brahui}

Brahui language is Dravidian. It is mainly spoken in the south-eastern regions of 
Pakistan. However some of its speakers are also to be found in Sorowak desert. The Brahui people who are estimated to be 700,000. Of them only 300,000 speak the language and the rest other regional language, such as Sindhi, Balochi, Pashto or Dari. All Brahui speakers are bilingual (Brown \& Ogilvie, 2009). In Afghanistan speakers of this language are estimated to be 200,000 living in Shorawa to Chakhansoor areas mixed with Afghan Baluchis (Lewis et al., 2015). In another account the speakers of Brahui are estimated to be 1.5 million. In their nomadic rendezvous some these people might have migrated into Afghanistan and there is currently an estimated population of 20,000 Brahui speakers in Afghanistan. Being settled in the context of Iranian languages, loan words and syntax of the grammars of Iranian languages had greatly changed Brahui language (Dalby, 2004) p.95.

\section{Other Minority languages of Afghanistan}

Due to diversity of languages in Afghanistan, the salient details of the languages that are not covered above, are given at the end in tabulated form. Data for the tables is taken from the official website of ethnologue (Lewis et al., 2015).

\section{Methodological Rich Points: Discussion and Conclusion}

To conclude, the preceding discussion on linguistic composition of Afghanistan presented it as a multilingual state with Pashto and Dari as the language of majority. Widespread bilingualism indicate internal integration process. However, some of the minority languages are threatened in recent past by the domination of Dari and Pashto languages. The use of Dari and Pashto in the domains of power raises concern about language rights of the minority language groups in Afghanistan. 
Tables. Diversity of Languages in Afghanistan: The Salient Details of the Languages

\begin{tabular}{|c|c|c|c|c|c|c|}
\hline \multicolumn{7}{|c|}{ Afghan Sign Language (ASL), Ashkun (Ashkund, Wamais) } \\
\hline L1 population & $\begin{array}{l}\text { L1 geographic } \\
\text { distribution }\end{array}$ & $\begin{array}{l}\text { Official } \\
\text { Status/L1 and } \\
\text { L2 literacy }\end{array}$ & EGIDS level & $\begin{array}{l}\text { Domains } \\
\text { present }\end{array}$ & $\begin{array}{l}\text { Language Tree } \\
\text { connection and } \\
\text { (dialects) }\end{array}$ & Comments \\
\hline ASL 1000 & $\begin{array}{l}\text { Mostly Urban areas } \\
\text { of Kabul, Jalalabad } \\
\text { and Kandahar city }\end{array}$ & Nil & 5 Developing & $\begin{array}{l}\text { Deaf School } \\
\text { education }\end{array}$ & $\begin{array}{l}\text { Influenced by } \\
\text { American Sign } \\
\text { Language }\end{array}$ & $\begin{array}{l}\text { Most users live in } \\
\text { Kabul city }\end{array}$ \\
\hline Ashkun 40,000 & $\begin{array}{l}\text { Pech valley in } \\
\text { Nuristan }\end{array}$ & $\begin{array}{l}\text { Nil/ L1 literacy } \\
\text { zero percent, L2 } \\
\text { literacy upto } \\
15 \%\end{array}$ & 6a Vigorous & $\begin{array}{l}\text { Oral poetry } \\
\text { (culture) }\end{array}$ & $\begin{array}{l}\text { Indo-Iranian, Indo- } \\
\text { Aryan, Nuristani. } \\
\text { (dialect: } \\
\text { Ashuruviri) }\end{array}$ & $\begin{array}{l}\text { 4,000 L1 speakers } \\
\text { monolingual other } \\
\text { bilingual in Pashto. } \\
\text { Sunni Muslims }\end{array}$ \\
\hline \multicolumn{7}{|c|}{ Degano (Wotapuri-Katarqalai), Gawarbati (Arandui, Gowari, Narisati, Narsati, Satre) } \\
\hline $\begin{array}{l}\text { Degano } \\
\text { Unspecified to } \\
\text { Nil }\end{array}$ & $\begin{array}{l}\text { Scattered } \\
\text { population in } \\
\text { Kunar, Watapur, } \\
\text { and Katar Kala }\end{array}$ & $\begin{array}{l}\mathrm{Nil} / 15-25 \% \text { in } \\
\text { Pashto }\end{array}$ & 9 (Dormant) & $\begin{array}{l}\text { Only by older } \\
\text { generation at } \\
\text { home }\end{array}$ & $\begin{array}{l}\text { Indo-Iranian, } \\
\text { Dadric, Kohistani }\end{array}$ & $\begin{array}{l}\text { Unwritten- } \\
\text { communication } \\
\text { lingua franca of } \\
\text { gypsies }\end{array}$ \\
\hline $\begin{array}{l}\text { Gawarbati } \\
32,000 \mathrm{~L} 1 \\
\text { speakers, and the } \\
\text { same ethnic } \\
\text { population }\end{array}$ & $\begin{array}{l}\text { Kunar Valley less } \\
\text { than } 10 \text { villages } \\
\text { along Konar river }\end{array}$ & $\begin{array}{l}\text { Nil/ literacy in } \\
\text { L2 up to } 15 \%\end{array}$ & $6 \mathrm{~b}$ (threatened) & $\begin{array}{l}\text { Interpersoal } \\
\text { use, mostly use } \\
\text { Pashto as L2 }\end{array}$ & $\begin{array}{l}\text { Indo-Iranian } \\
\text { (Lexical similarity: } \\
\text { Shumashti, Daeli } \\
\text { and Savi, } 47 \% \text {, } \\
44 \% \text { and } 42 \% \\
\text { respectively) }\end{array}$ & Unwritten. \\
\hline
\end{tabular}




\begin{tabular}{|c|c|c|c|c|c|c|}
\hline \multicolumn{7}{|c|}{$\begin{array}{l}\text { Grangali (Geangali, Jumiaki), Gujari (Gojari, Gojri, Gujuri Rajasthani), Inku (Jakati, Jat, Jataki, Jati, Jatu, } \\
\text { Kayani, Musali) and Ishkashimi (Eshkashimi, Ishkashmi) }\end{array}$} \\
\hline L1 population & $\begin{array}{l}\text { L1 geographic } \\
\text { distribution }\end{array}$ & $\begin{array}{l}\text { Official } \\
\text { Status/L1 and } \\
\text { L2 literacy }\end{array}$ & EGIDS level & $\begin{array}{l}\text { Domains } \\
\text { present }\end{array}$ & $\begin{array}{l}\text { Language Tree } \\
\text { connection and } \\
\text { (dialects) }\end{array}$ & Comments \\
\hline $\begin{array}{l}\text { Grangali } \\
5,000\end{array}$ & $\begin{array}{l}\text { Grangali and } \\
\text { Zemiaki villages in } \\
\text { Pech valley }\end{array}$ & $\begin{array}{l}\text { Nil/ L2 Literacy } \\
\text { up to } 15 \%\end{array}$ & 6a Vigorous & $\begin{array}{l}\text { Local } \\
\text { interpersoanl }\end{array}$ & $\begin{array}{l}\text { Indo- } \\
\text { Iranian/Dardic. } \\
\text { Lexical similarity: } \\
63 \% \text { Shumashti, } \\
\text { 42\% Gawar-Bati } \\
\text { (dialects: } \\
\text { Nangalami, } \\
\text { zemiaki) }\end{array}$ & $\begin{array}{l}\text { Unwritten, } \\
\text { Namagali dialect } \\
\text { has become extinct }\end{array}$ \\
\hline $\begin{array}{l}\text { Inku } \\
\text { Unknown or nil }\end{array}$ & $\begin{array}{l}\text { Balkh, Faryab, } \\
\text { Herat and Kunduz }\end{array}$ & No information & 9 (Dormant) & None & $\begin{array}{l}\text { Indo-Iranian, } \\
\text { Panjabi, Western } \\
\text { Panjabi }\end{array}$ & \\
\hline $\begin{array}{l}\text { Gujari } \\
2,000\end{array}$ & $\begin{array}{l}\text { Nomads in eastern } \\
\text { valley }\end{array}$ & Nil & $6 \mathrm{~b}$ Threatened & $\begin{array}{l}\text { Older } \\
\text { generation } \\
\text { home }\end{array}$ & Indo-Iranian & \\
\hline Ishkashimi2,500 & $\begin{array}{l}\text { North of Ishkashim } \\
\text { town }\end{array}$ & $\begin{array}{l}\text { Nil/ L2 literacy } \\
\text { rate upto } 25 \%\end{array}$ & $6 \mathrm{~b}$ Threatened & $\begin{array}{l}\text { Older } \\
\text { generation } \\
\text { home }\end{array}$ & $\begin{array}{l}\text { Iranian/Pamiri } \\
\text { (lexical similarity: } \\
70 \% \text { with } \\
\text { Sanglechi) }\end{array}$ & $\begin{array}{l}\text { L1 unwritten. All } \\
\text { are bilingual in } \\
\text { Dari }\end{array}$ \\
\hline
\end{tabular}




\begin{tabular}{|c|c|c|c|c|c|c|}
\hline \multicolumn{7}{|c|}{$\begin{array}{l}\text { Kamviri (Kamdeshi, Kamik, Shekhani, Lametiviri), Kati (Bashgali, Kativiri, Nuristani), Kyrghiz (Kirghiz, } \\
\text { Kirghizi, Kirghiz tili) }\end{array}$} \\
\hline L1 population & $\begin{array}{l}\text { L1 geographic } \\
\text { distribution }\end{array}$ & $\begin{array}{l}\text { Official } \\
\text { Status/L1 and } \\
\text { L2 literacy }\end{array}$ & EGIDS level & $\begin{array}{l}\text { Domains } \\
\text { present }\end{array}$ & $\begin{array}{l}\text { Language Tree } \\
\text { connection and } \\
\text { (dialects) }\end{array}$ & Comments \\
\hline Kamviri 18,000 & $\begin{array}{l}\text { Bashgal valley, } \\
\text { Kishtoz and } \\
\text { Kamdesh village }\end{array}$ & $\begin{array}{l}\text { Nil / L2 literacy } \\
\text { at } 10 \%\end{array}$ & 6a vigorous & All domains & $\begin{array}{l}\text { Indo-Iranian } \\
\text { (dialects: Shekhani) }\end{array}$ & $\begin{array}{l}3,600 \mathrm{~L} 1 \\
\text { monolingual the } \\
\text { rest bilingual }\end{array}$ \\
\hline $\begin{array}{l}\text { Kati } 15000 \text { (with } \\
114,000 \text { whole } \\
\text { ethnic } \\
\text { population) }\end{array}$ & $\begin{array}{l}\text { Mondul, Duab, } \\
\text { Ramgal, Kulam, } \\
\text { Ktivi and Paruk } \\
\text { valleys }\end{array}$ & $\begin{array}{l}16(2) \\
\text { consitutional at } \\
\text { provincial level/ } \\
\text { L1 literacy zero } \\
\text { per cent, L2 } \\
\text { literacy upto 3\% }\end{array}$ & 6a vigorous & $\begin{array}{l}\text { All domains. } \\
\text { Textbook in } \\
\text { Kati for use in } \\
\text { schools are } \\
\text { under } \\
\text { production. }\end{array}$ & $\begin{array}{l}\text { Indo-Iranian } \\
\text { /Nuristani (dialects: } \\
\text { Eastern Kativiri, } \\
\text { Mumviri, Western } \\
\text { Kativiri) }\end{array}$ & $\begin{array}{l}\text { Lingua Franca in } \\
\text { Nuristan. Speakers } \\
\text { use Pashto and } \\
\text { Dari as L2. }\end{array}$ \\
\hline Kyrgyz 1200 & $\begin{array}{l}\text { Extreme North in } \\
\text { Great and Little } \\
\text { Pamir }\end{array}$ & & $\begin{array}{l}5 \text { vigorous and in } \\
\text { use }\end{array}$ & & Altaic/Turkic & \\
\hline \multicolumn{7}{|c|}{$\begin{array}{l}\text { Mogholi (Moghol, Mogul, Mongul), Munji (Munjani, Munjingi, Munijwari), Omuri (Barkas, Bargista, Oomuri, } \\
\text { Omui), Pahlavani and Parya (AfghanaYi, Nasfurush, Afghanyi, Siyarui, Laghmi), Tregami (Katar, Gambir, } \\
\text { Trigami), }\end{array}$} \\
\hline $\begin{array}{l}\text { Mogholi } 2000 \\
\text { ethnic group with } \\
\text { no L1 speaker }\end{array}$ & $\begin{array}{l}\text { Vicinity of Herat, } \\
\text { Kundur and Kariz- } \\
\text { i-Mulla villages }\end{array}$ & Nil & 9 Dormant & & $\begin{array}{l}\text { Altaic /Mongolic } \\
\text { (Dialects: Karez-I- } \\
\text { Mulla, Kundur) }\end{array}$ & Unwritten \\
\hline
\end{tabular}




\begin{tabular}{|c|c|c|c|c|c|c|}
\hline $\begin{array}{l}\text { Munji 5,300 } \\
\text { (very few } \\
\text { monolinguals) }\end{array}$ & $\begin{array}{l}\text { North-eastern } \\
\text { areas }\end{array}$ & $\begin{array}{l}16(2) \text { statutory } \\
\text { language of } \\
\text { Badakhshan, } \\
\text { provincial } \\
\text { identity/ L1 } \\
\text { literacy below } \\
1 \%, \text { L2 literacy } \\
\text { upto } 25 \%\end{array}$ & 6a Vigorous & $\begin{array}{l}\text { Informal. } \\
\text { Forms group } \\
\text { identity, that is } \\
\text { kept exclusive } \\
\text { to group } \\
\text { members, } \\
\text { poetry and } \\
\text { dictionary } \\
\text { being present }\end{array}$ & $\begin{array}{l}\text { Indo-Iranian/ Pamiri. } \\
\text { (Dialect: Northern } \\
\text { Munji, Souther } \\
\text { Munji) }\end{array}$ & $\begin{array}{l}\text { All speakers are } \\
\text { bilingual in Dari }\end{array}$ \\
\hline $\begin{array}{l}\text { Omuri } \\
\text { 2050(2011) Total } \\
6050\end{array}$ & Logar & Nil & $8 b$ (Nearly extinct) & $\begin{array}{l}\text { Poetry, written } \\
\text { dictionary }\end{array}$ & $\begin{array}{l}\text { Indo-Iranian } \\
\text { /Ormuri-Parachi } \\
\text { (Dialects: } \\
\text { Kanigurami) 27\% } \\
\text { lexical similarity } \\
\text { with Waneci, 30\% } \\
\text { with Pashto) } \\
\end{array}$ & $\begin{array}{l}\text { None speak it as } \\
\text { L1 in Afghanistan }\end{array}$ \\
\hline $\begin{array}{l}\text { Pahlavani } \\
\text { Zero }\end{array}$ & $\begin{array}{l}\text { Chakhansur } \\
\text { district }\end{array}$ & Nil & 9 Dormant & None & Indo-Iranian/Persian & Similar to Dari \\
\hline $\begin{array}{l}\text { Parya } 240 \text { ethnic } \\
\text { community }\end{array}$ & Kunduz province & & 9 (Dormant) & & $\begin{array}{l}\text { Unclassified in Indo- } \\
\text { Iranian }\end{array}$ & No L1 speaker \\
\hline \multicolumn{7}{|c|}{$\begin{array}{l}\text { Pashayi (Pashai), Sanglechi (Dargi), Prasuni (Parun, Paruni, Prasun, Veron, Verou), Savi (Sau, Sauji, Sawi), } \\
\text { Shumashti (Shumasht), Tirahi, Tregami (Katar, Gambir, Trigami), Waigali ((Suki, Wai, Wai-Ala, Waigala, } \\
\text { Waigalii, zhonjigali), Warduji and (Wotapuri-Katarqalai) }\end{array}$} \\
\hline Pashayi 600,000 & $\begin{array}{l}\text { North of Kabul, } \\
\text { Sarobi, Tagau } \\
\text { valley, Darrai Nur } \\
\text { valley, Damench, } \\
\text { Nangrahar } \\
\text { province, Kapisa } \\
\text { and Laghman } \\
\text { provinces }\end{array}$ & $\begin{array}{l}\text { Provincial } \\
\text { statutory } \\
\text { protected/ }\end{array}$ & 6a Vigorous & All domains & $\begin{array}{l}\text { Indo-iranian } \\
\text { /Dardic/ pashayi } \\
\text { (northeast, } \\
\text { northwest, southeast } \\
\text { and southwest) }\end{array}$ & $\begin{array}{l}\text { Dialects have } \\
\text { similarity of } 30 \%\end{array}$ \\
\hline
\end{tabular}




\begin{tabular}{|c|c|c|c|c|c|c|}
\hline $\begin{array}{l}\text { Sanglechi } \\
2,200\end{array}$ & $\begin{array}{l}\text { Badakhshan } \\
\text { province }\end{array}$ & & 6a vigorous & & $\begin{array}{l}\text { Indo-Iranian/ } \\
\text { Pamiri, } 70 \% \\
\text { similarity with } \\
\text { Ishkashimi }\end{array}$ & Ismaili Shia \\
\hline $\begin{array}{l}\text { Prasuni } 8,000 \\
(1600 \\
\text { monolingual L1 } \\
\text { users) }\end{array}$ & Nuristan province & $\begin{array}{l}\text { Nil/ L2 literacy } \\
15 \%, \\
\text { traditionally } \\
\text { bilingual in Dari }\end{array}$ & 6a vigorous & All domains & $\begin{array}{l}\text { Indo- } \\
\text { Iranian/Nuristani } \\
\text { (Dialects: central } \\
\text { and lower Prasun) }\end{array}$ & $\begin{array}{l}\text { It is most unique } \\
\text { Nuristani language } \\
\text { with little mutual } \\
\text { understanding }\end{array}$ \\
\hline Savi 3,000 & Sau Village & Nill/ & 6a vigorous & All & $\begin{array}{l}\text { Indo-Iranian, } \\
\text { Dardic, Shina }\end{array}$ & $\begin{array}{l}58 \% \text { similar to } \\
\text { Palula }\end{array}$ \\
\hline $\begin{array}{l}\text { Shumashti } \\
1,000\end{array}$ & Kunar valley & & & & $\begin{array}{l}\text { Indo-Iranian, } \\
\text { Dardic, lexical } \\
\text { similarity at } 47 \% \\
\text { Gawar-Bati and } \\
63 \% \text { with Grangali, } \\
\text { heavy influence of } \\
\text { Pashayi }\end{array}$ & \\
\hline $\begin{array}{l}\text { Tirahi } 100 \text { in } \\
\text { Afghanistan, } \\
\text { Total is 5,000 }\end{array}$ & $\begin{array}{l}\text { Souteast of } \\
\text { Jalalabad and } \\
\text { Nangrahar } \\
\text { province }\end{array}$ & Nill & 8b Nearly Extinct & & $\begin{array}{l}\text { Indo-Iranian, } \\
\text { Dardic, Kohistani } \\
\text { closely related to } \\
\text { Kohistani }\end{array}$ & $\begin{array}{l}\text { This group is } \\
\text { completely } \\
\text { assimilated by } \\
\text { Pashtuns/ } \\
\text { Unwritten }\end{array}$ \\
\hline $\begin{array}{l}\text { Tregami } 3,500 \\
\text { (700 monolingual } \\
\text { L1 users) }\end{array}$ & $\begin{array}{l}\text { Nuristan Province, } \\
\text { Want, Tregam } \\
\text { valley }\end{array}$ & Nil & 6a vigorous & & $\begin{array}{l}\text { Indo-Iranian, } \\
\text { Nuritani. 80\% } \\
\text { similar to Waigali }\end{array}$ & $\begin{array}{l}\text { Tregami can be } \\
\text { treated as dialect of } \\
\text { waigali }\end{array}$ \\
\hline $\begin{array}{l}\text { Waigali } 11,500 \\
(2300 \\
\text { monolingual L1 } \\
\text { speakers) }\end{array}$ & $\begin{array}{l}\text { Nuristan Province } \\
\text { (south east) }\end{array}$ & & 6a vigorous & & $\begin{array}{l}\text { Indo- } \\
\text { Iranian/Nuristani } \\
\text { (Dialects: Chima- } \\
\text { Nishey, Vargan) } \\
\end{array}$ & \\
\hline
\end{tabular}




\begin{tabular}{|l|l|l|l|l|l|l|}
\hline & & & & $\begin{array}{l}80 \% \text { lexical } \\
\text { similarity with } \\
\text { Tregami }\end{array}$ & \\
\hline Warduji 5,000 & $\begin{array}{l}\text { Northeast, } \\
\text { Werdoge river } \\
\text { area }\end{array}$ & & 6a Vigorous & $\begin{array}{l}\text { Probably a Dari } \\
\text { dialect }\end{array}$ & \\
\hline $\begin{array}{l}\text { Wotapuri } \\
\text { Zero L1 speakers }\end{array}$ & Nuristan & 10 Extinct & $\begin{array}{l}\text { Indo- } \\
\text { Iranian/Dardic/Kohi } \\
\text { stani }\end{array}$ & \\
\hline
\end{tabular}


Geographic, Ethnic and Linguistic Composition of Afghanistan: Methodological rich points of

Language Policy and Planning

\section{References}

Alsanov, M., Gafferberg, E., Kisliakov, N., Zadykhina, K., \& Vasilyeva, G. (1969). Ethnography of Afghanistan (M. a. G. Slobin, Trans.). In G. L. Grassmuck (Ed.), Afghanistan: Some New Approaches. Ann Arbor University of Michigan.

Bacon, E. E. (1951). The Hazara Mongols of Afghanistan a study in social organization. (PhD Dissertation), University of California, Berkeley, Calif.

Barfield, T. J. (1981). The central Asian Arabs of Afghanistan : pastoral nomadism in transition. (Originally presented as the author's thesis ( $\mathrm{Ph}$ D), Harvard, 1980), Austin.

Bellew, H. W. (1879). Afghanistan and the Afghans: being a brief review of the history of the country, and account of its people, with a special reference to the present crisis and war with the Amir Sher Ali Khan. London,: Sampson Low, Marston, Searle, \& Rivington.

Bellew, H. W. (1880). The Races of Afghanistan: A Brief Account of the Principal Nations Inhabiting that Country. Calcutta: Thacker, Spink, And Co.

Bleuer, C. M. (2007). Uzbek versus the Center: Mobilization as an Ethnic Minority in the Tajikistan and Afghanistan Civil Wars. (Master of Arts), Indiana University, US.

Boutros-Ghali, B. (1992). An agenda for peace: Preventive dimplomacy, peacemaking and peace-keepping. New York: United Nations.

Dupree, L. (1973). Afghnistan. Princeton, New Jersey: Princeton University Press.

Dupree, N. H., \& Gouttierre, T. E. (2001). Chapter 2. The Society and its Environment A Country Study: Afghanistan (pp. 28-70). Baton Rouge, LA: Claitor's Pub. Division Library of Congress.

Eide, A. (1993). In Search of Constuctive Alternatives to Secession. In C. Tomuschat (Ed.), Modern law of sel-determination (pp. 123-127). Dordrecht, Boston, London: Martinus Nijhoff Publishers.

Fawcett, C. B. (1919(1961)). Provinces of England. London: Hutchinson \& Co. 
Ferrier, J. P. (1857). caravan Journeys and Wanderings in persia, Afghanistan, Turkistan and Baluchistan, with histoircal notices on the countries lying between Russia and India. Londo: John Murray.

Fishman, J. A. (1971). The sociology of language: An interdisciplinary social science approach to language in society. In J. Fishman (Ed.), Advances in the Sociology of Language (pp. 217-258). The Hague: Mouton.

Fraser-Tytler, W. K. (1967). Afghanistan: A Study of Political Development in Central and Southern Asia. London: Oxford University Press.

Freeman, T. W. (1958). Goegraphy and Planning. London: Hutchinson \& Co.

Freeman, T. W. (1968). Goegraphy and Regional Administration London Hutchinson \& Co.

Ginsburg, N. (Ed.). (1958). The Pattern of Asia Englewood Cliff, NJ: PrenticeHall, Inc.

Goodson, L. P. (1998). The Fragmentation of Culture in Afghanistan. Alif: Journal of Comparative Politics, 18, 269-289.

Goodson, L. P. (2001). Afghanistan's Endless War. Seattle University of Washington Press.

Gopalakrishnan, R. (1982). The Geography and Politics of Afghanistan. New Delhi: Concept Publishing Company.

Grevemeyer, J.-H. (1987). Afghanistan: Sozialer Wandel und Staat im 20. Jahrhundert. Berlin.

Habibi, A. A. H. (1962). Afghanistan Baad az Islam (Afghanistan Following Islam). Tehran: dunya e Ketab.

Hamilton, A. (1910). Afghanistan (Vol. XVIII). Boston: J.B. Millet Company.

Harpviken, K. B. (2009). Social Newworks and Migration in Wartime Afghanistan. Basingstoke: Palgrave Macmillan.

Holdich, T. H. (1904). India. London: Henry Frowde.

Holdich, T. H. (1987). The Indian Borderland, 1880-1900. Delhi, India: Gian Publishing 
Geographic, Ethnic and Linguistic Composition of Afghanistan: Methodological rich points of Language Policy and Planning

Hornberger, N. H. (2013). Negotiating methodological rich points in the ethnography of language policy. International Journal of the Sociology of Language, 219, 101-122.

Hornberger, N. H. (2015). Selecting Appropriate Research Methods in LPP Research: Methodological Rich Points. In F. M. Hult \& D. C. Johnson (Eds.), Research Methods in Language Policy and Planning: A Practical Guide (pp. 9-21). West Ussex, UK: Wiley Blackwell.

Hussain, M. (2003). The Hazaras of Afghanistan: A Study of Ethnic Relations (Master of Arts), McGill University

Jawad, N. (1992). Afghanistan: A Nation of Minorities (Vol. 92/2). London: Minorities Rights Group International.

Johnson, C. (2000). Hazrajat: Kinship and Neighborhood in the Village. In S. Akhavi (Ed.), Middle East studies : History, politics, and law. New York; London: Routledge.

Khashimbekov, K. (1994). Uzbeki Severnogo Afganistana. Moskva: Rossiyskaya Akademiya Nauk: Institut Vostokovediniya.

Kieffer, C. M. (2009). Parachi. In G. Windfuhr (Ed.), The Iranian Languages (pp. 693-720). London: Routledge.

Kimminich, O. (1993). A "Federal" Right of Self-Determination? . In C. Tomuschat (Ed.), Modern Law of Self-Determination (pp. 83-100). Dordrecht, Boston, London: Martinus Nijhoff Publishers.

Lewis, M. P., Simons, G. F., \& Fennig, C. D. (Eds.). (2015). Ethnologue: Languages of Afghanistan (Eighteenth Edition ed.). Dallas, Texas: SIL International.

Lijphart, A. (1996). Nagorny Karabakh's right to State Independence According to International Law. Berlin: Foundation of Armenian Studies.

Magnus, R. H., \& Naby, E. (1998). Afghanistan: Mullah, Marx, and Mujahid. Colorodo: Westview Press.

Maley, W. (1998). Fundamentalism reborn? : Afghanistan and the Taliban. New York: New York University Press.

Mousavi, S. A. (1998). The Hazaras of Afghanistan: An Historical, Cultural, Economic and Political Study. Surrey: Curzon Press. 
Naby, E. (1984). The Uzbeks in Afghanistan. Central Asian Survey, 3(1), 1-22.

Orazgani, M. A. (1913). Al Manqul fi Tehrik-e-Hazara wa Moghol (Narrative of Hazara and Moghul Movement). Quetta.

Orywal, E. (1983). Verbreitungskarte der etnischen Gruppen Afghanistans. TAVO-Blatt, 8(6).

Poladi, H. (1989). The Hazaras: History, Culture, Politics and Economy. California: Moghol Pub. Co.

Prescot, J. R. V. (1968). The Geography of State Policies. London: Hutchinson.

Prescot, J. R. V. (1972). Political Geography. London: Methuen.

Pstrusinska, J. (1990). Afghanistan 1989 in Sociolinguistic Perspective. Central Asian Survey(7), 3-17.

Qums. (1983). History of Qums. Isfahan: Qums Publications.

Rais, R. B. (1999). Conflict in Afghanistan. Ethnic Studies Report, 17(1), 1-17.

Ramazani, R. K. (1966). The Northern Tier: Afghanistan, Iran and Turkey. New Jersey: Princeton.

Rashid, A. (2000). Taliban: Islam, oil and the new great game in Central Asia. London; New York: I.B. Tauris.

Ricento, T. (2000). Historical and theoretical perspective in language policy and planning. JOURNAL OF SOCIOLINGUISTICS, 4(2), 196-213.

Ryan, S. (1995). Ethnic Conflcit and International Relation (2nd ed.). Aldershot, Brookfield USA: Dartmouth.

Sarabi, H. (2006). Politics and Modern History of Hazara: Sectarian Politics in Afghanistan. (Master of Arts in Law and Diplomacy), Tufts University.

Schurman, H. F. (1962). The Mongols of Afghanistan: An Ethnograpy of the Moghals and Related Peoples of Afghanistan. The Hague: Mouton.

Schurmann, H. F. (1962). The Mongols of Afghganistan : an ethnography of the Monghols and related peoples of Afghanistan. 'S-Gravenhage: Mouton \& Co. 
Shahrani, M. N. (1998). The Future of the state and the Structure of Community Governance in Afghanistan. In W. Maley (Ed.), Fundamentalism Reborn? Afghanistan and the Taliban New York: Yew York University Press.

Shahrani, M. N. (2002). War, Factionalism, and the State in Afghanistan. American Anthropologist, 104(3), 715-722.

Shahrani, M. N. (2013). Kirghiz and Wakhi of Afghanistan : Adaptation to Closed Frontiers (Vol. 1 ). Vancouver, BC, CAN: University of Washington Press.

Sharistani, S. A. A. (1981). Qamus-i-Lahja-e-Hazargai e Dari (Dictionary of Hazargai and Dari dialects). Kabul.

Simonsen, S. G. (2004). Ethnicising Afghanistan?: Inclusion and exclusion in post-Bonn institution building. Third World Quarterly, 25(4), 707-729.

Sollors, W. (1986). Beyond Ethnicity: Consent and Descent in American Culture. New York: Oxford University Press.

Stamp, L. D. (1967). Asia: a regional and economic geography (12 ed.). London: Methuen.

Tapper, N. (1991). Bartered Brides: Politics, Gender and Marriage in an Afghan Tribal Society. Cambridge: UK: Cambridge University Press.

Tapper, R. (1984). Ethnicity and Class: Dimensions of Conflict. In M. N. Shahrani \& R. L. Canfield (Eds.), Revlutions and Rebellions in Afghanistan. Berkeley: University of California.

Wirsing, R. G. (1987). The Baluchis and Pathans. London: Minorities Rights Group International.

Zangwill, I. (1909/1921). Works of Israel Zangwill: The Melting Pot. New York: The American Jewish Book Company. 